\title{
Energy Saving and Energy Service: Economic Policy and Market Prospects
}

\author{
Polyanskaya O.A. \\ Saint Petersburg State Forest Technical University, \\ Saint Petersburg, Russia, \\ Polyanskaya_78@mail.ru \\ Tatarenko V.N. \\ Saint Petersburg State Forest Technical University \\ Saint Petersburg, Russia, \\ vntat26@mail.ru
}

\author{
Bespalova V.V. \\ Saint Petersburg State Forest Technical University, \\ Saint Petersburg, Russia, \\ weronika2002@yandex.ru
}

Okomina E.A.

Yaroslav the Wise Novgorod State University, Veliky Novgorod, Russia,

Ekaterina.Okomina@novsu.ru

\author{
Vasilyeva L.P. \\ "Military University" of the Ministry of Defense of the Russian Federation, \\ Moscow, Russia, \\ luda700619@mail.ru
}

\begin{abstract}
At the end of 2010, the Government of the Russian Federation adopted the program: "Energy Saving and Energy Efficiency Improvement". This program provides for the replacement of devices of all kinds of energy resources for all participants in the energy market. At the same time, the realities of the market economy, the specifics of federal legislation, the general economic situation, the economic crisis, to some extent managerial conservatism, as well as international experience in the application of energy service technologies make significant adjustments to this process, which determine the situation in the energy service market. In accordance with the 2009 Law of the Russian Federation on Energy Efficiency, the market initiator for the implementation of energy saving programs is an energy service company that provides the corresponding type of services. The most commonly used types of energy services in Russia include energy audits, the development of energy saving programs for customer facilities, and a fairly wide range of various types of energy service contracts. Despite the significant lag of the Russian Federation in terms of energy efficiency, it should be noted that many parameters characterizing the market for energy services in the Russian Federation and in Western countries have signs of both qualitative and structural similarities.
\end{abstract}

Keywords-energy service, energy saving, energy service companies, energy consumption, energy service market, energy efficiency

\section{INTRODUCTION}

The problems that are associated today with energy saving, as well as with increasing the energy efficiency of economic facilities are classified as top-priority, as for individual economic units (enterprises of any profile and various types of property and forms of management, objects of federal and municipal administration, apartment buildings, private households, etc. etc.), and for the state as a whole [1,2].

An important stimulating moment in the development of the market of services of energy service companies was the adoption in 2009 of the Federal Law No. 261-FZ "On Energy Saving and on Increasing Energy Efficiency", which regulates relations between economic entities on energy saving, efficient energy consumption and the use of all types of energy resources, taking into account production - technological, ecological and socio-economic conditions. The main postulates of the above law are the creation of both legal and economic and organizational foundations that stimulate enterprises, organizations acting as owners of real estate objects to rational use of energy resources and increase their energy efficiency. 10 years have passed since the adoption of the Law, and, on the one hand, after this time, some significant shifts can be noted, indicating that the concept of energy conservation is becoming an important component of the modern style of economic thinking and the modern approach to the management of urban and industrial infrastructure [3]. 
On the other hand, in the field of energy services, there are still many unsolved problems of a very different nature: organizational, financial, problems of interaction of energy service enterprises with state and municipal structures, methodological problems associated with the development of methods for objectively determining and calculating the effect (in the form of real energy savings) from work performed as required by law. The shortage of funds in the organizations of municipal administration leads, in particular, to low indicators in terms of equipping budgetary organizations with AIHS (automated individual heating stations). The reason for this is the relative high cost of such equipment, which can range from 1 to 3 or more million rubles.

If we talk about the individual components of the energy service (comprehensive energy audit, as well as its various options, such as thermal imaging diagnostics of buildings, structures, equipment and other infrastructure facilities, drawing up energy certificates of residential and industrial facilities, conducting examinations on the efficiency of energy consumption, energy consulting, development of energy saving programs, energy efficient lighting, development of complex energy saving projects focused on a specific object, production of works and provision of services within the framework of the implementation of energy saving projects...), it should be noted that today the state of affairs in these various components of energy service is very different and in general it cannot be said that energy service in our country has developed into a single systemically balanced sector of the national economy [4].

A serious problem is the high degree of uncertainty in the energy services market, due to general economic instability and financial problems in municipal organizations and enterprises that are the main consumers of energy services. Such volatility in conditions and cumulative circumstances requires energy service companies to understand the leading trends and dynamics inherent in this market [5].

\section{PROBLEM STATEMENT}

Energy efficiency today should be considered not only as a necessity imposed by law and market conditions, but also as one of the key bases that set a new paradigm of modern economic development. Due to this, the task of increasing energy efficiency should become one of the priorities of economic policy both at the federal level and at the local level, making maximum use of international experience in organizing energy services and the possibilities of system partnership between public and private business structures professionally focused on the provision of energy services.

\section{RESEARCH QUESTIONS}

The main research questions formulated in the work and acting as research objectives are the following:

- Market prospects for the development of energy services in sectors of the national economy with energy saving potential in the context of the economic policy pursued at the federal and local levels.

- Use of international experience in the field of energy service technologies to improve the energy efficiency of industrial and human life support infrastructure.

\section{PURPOSE OF THE STUDY}

The purpose of the study is to show the possibilities for the development of energy services mainly in energy inefficient areas of management, taking into account the use of international experience in the application of energy saving and energy service technologies.

\section{RESEARCH METHODS}

The research is based on the following methods: qualitative, comparative and situational analysis, structural analogies and systemic generalizations.

\section{FINDINGS}

Historically, a key prerequisite for the development of energy conservation programs and the rational use of energy resources in the economies of Western countries was the 1973-1974 energy crisis, which had such a strong impact on the world economy that some Western economists compared it with the Great Depression of 1929-1933.

In turn, restrictive measures on energy consumption, as well as techniques and technologies for energy saving contributed to the successful solution of environmental problems of industrial development, which since that time have become an important component of the economic policy of developed countries [6].

The energy crisis affected the economy of the Soviet Union in a completely different way. The powerful flow of petrodollars that poured out as a result of the rise in price of the basic energy resource could not be absorbed by the country's economy, because the then leadership could not or did not want to work out an instrument for investing these funds for the purposes of accelerated internal development. As a result, huge funds accumulated in the form of foreign exchange earnings, including in Western banks, eventually working for the Western economy. This period was the beginning of the systemic lag of the USSR economy from the economy of developed Western countries

The planned economy of the USSR ignored the energy saving factor. Before the Khrushchev reforms, and, later, the Kosygin reforms, the basic indicators on which the enterprise reported directly stimulated production managers to save all types of resources, since to reduce the cost of production was considered one of the main priorities. And in the late USSR, energy conservation issues were constantly on the agenda, but how all this was implemented in the real activities of industry leaders, in everyday economic practice is another matter [7].

From an economic point of view, an important innovation of that time, stimulating suppliers and consumers of energy resources to real savings, was the introduction of such an indicator as "saved energy", which for the supplier meant the opportunity to sell it to another consumer, while receiving additional profit (provided that consumers will use more economical equipment). In order to interest the consumer and stimulate him to buy more economical but, as a rule, more expensive equipment (for example, a refrigerator), the calculated indicator "cost of energy saved" was used, expressed in cents per $1 \mathrm{kWh}$ of saved energy when using new equipment. This strategy worked successfully, and from now on, the tradition of energy saving has become one of the 
dominants of economic behavior characteristic of both enterprises - business entities and individual citizens, eventually becoming the idee fixe of a typical inhabitant of Western Europe [8].

In domestic practice, energy-saving technologies began to be used only after 2009 . Until that time, the concept of "energy service" and "energy service contract" were not used in practice. Industrial enterprises either engaged in energy conservation at their own discretion, hiring contractors or outsourced this area to external engineering companies. In the public sector, public procurement legislation allowed the purchase of equipment only at the lowest prices, and the Budget Code did not allow state and municipal customers to enter into contracts if their term exceeded the three-year budget cycle [9].

If we talk about the problem as a whole, the task of improving energy efficiency for the Russian economy is still urgent, as evidenced by the estimates of the International Energy Agency regarding the comparative (specific) energy intensity of the RF GDP: in Russia this indicator is 11 times higher than in Germany, 6 times higher than in Canada, 4 times higher than in Poland [11].

In relative terms, the energy saving potential in the Russian Federation from typical measures for the modernization of energy supply and energy consumption systems is presented below in Table 1 .

TABLE I. EXPECTED RESOURCE SAVINGS FROM ENERGY EFFICIENCY MEASURES

\begin{tabular}{|c|l|c|}
\hline № & \multicolumn{1}{|c|}{$\begin{array}{c}\text { Type of energy supply } \\
\text { and energy saving measures }\end{array}$} & $\begin{array}{c}\text { Expected } \\
\text { annual savings, \% }\end{array}$ \\
\hline 1 & Heating systems, including: & 53 \\
\hline 1.1 & Equipping with energy meters & 27 \\
\hline 1.2 & $\begin{array}{l}\text { Automation of heating systems by installing } \\
\text { individual heating stations (IHS) }\end{array}$ & 21 \\
\hline 1.3 & Transmission losses reduction & 48 \\
\hline 1.4 & Thermal insulation of walls, floors ... & 17 \\
\hline 2 & $\begin{array}{l}\text { Hot water supply systems (DHW), } \\
\text { including: }\end{array}$ & 12 \\
\hline 2.1 & Equipping with hot water meters & \\
\hline 2.2 & $\begin{array}{l}\text { Reduced consumption through cost } \\
\text { optimization and temperature control }\end{array}$ & \\
\hline
\end{tabular}

Other energy-saving measures of a technical nature, implemented within the framework of energy service contracts, include the following: installation of automated heat consumption control units; installation of motion and presence sensors; modernization of outdoor and indoor lighting.

In accordance with the 2009 Law of the Russian Federation on Energy Efficiency, an energy service company that provides the corresponding type of services acts as the market initiator for the implementation of energy conservation programs. The most commonly used types of energy services in Russia include energy audits, the development of energy saving programs for customer facilities, and a fairly wide range of various types of energy service contracts. Among the reasons hindering the development of the energy service market, in addition to some aspects of a legal nature, some experts note the following: low awareness and technical unpreparedness of the personnel of budgetary organizations in the field of energy saving; lack of methodology for the implementation of energy service contracts in budgetary areas, including in the issue of payment for the services of energy service companies; weak customer interest in achieving savings of energy and budgetary funds; low level of oversight by government agencies responsible for energy conservation programs; inadequate sanitary and technical condition of facilities and their unpreparedness for energy-saving measures.

For comparison, in world practice, the forms of energy service contracts are more diverse, and the interactions between the customer or consumer of energy services are more mutually motivated [12]

The most common forms of relations in the field of energy services abroad are the following: provision of consulting services; supply of energy-saving equipment; recommendations for energy saving measures; complex services (including the development and implementation of a turnkey project); energy supply contracts; Chauffage contracts; energy management contracts; performance contracts; leasing agreements with the right to transfer ownership; connection of energy service with property management (full management) [13]

The settlement procedure between the customer and the energy service company abroad also has more diverse forms than in the Russian Federation and can provide both a lump sum payment made upon completion of the energy service project and a phased payment; in this case, the amount of the payment may provide for the option when it does not depend on economy, as well as the option when the amount of the payment depends on the actually achieved economy [14]. Below in Table 2 are some of the economic policy features most successful in terms of energy efficiency.

\section{RESULTS AND DISCUSSION}

In general, despite the significant lag of the Russian Federation in terms of energy efficiency, it can be noted within the framework of a comparative analysis that many parameters characterizing the energy service market in the Russian Federation and in Western countries have signs of both qualitative and structural similarities. Despite the fact that the vector of development of the Russian energy service largely coincides with the "mainstream" of global trends in energy saving and energy efficiency, the scope of the upcoming work is so significant that it is premature to speak today of energy service as an industry that has entered a phase of market maturity [15]. Thus, the following conclusions can be drawn regarding the opportunities for the development of the energy services market in the Russian Federation (which, as we see it, in the long term depends little on the emerging socio-economic conditions due to the fact that this megatrend is global in nature and has no alternatives):

- The development of the energy services market in the Russian Federation has great development potential. 
- The main incentives for market development today are both the real needs of the economy and energy-saving government programs to reduce energy consumption.

- The main obstacles to the development of the energy service market are: imperfect legislation, poor information work of the authorities, methodological difficulties associated with determining the actually achieved energy savings, as well as problems of financing energy service projects.

TABLE II. FEATURES OF ECONOMIC POLICIES OF THE COUNTRIES LEADING IN THE FIELD OF ENERGY SAVING AND ENERGY EFFICIENCY

\begin{tabular}{|c|c|}
\hline USA & $\begin{array}{l}\text { There is a Federal Energy Management Program } \\
\text { (FEMP) in place to pursue investment policies } \\
\text { aimed at improving energy efficiency. }\end{array}$ \\
\hline Germany & $\begin{array}{l}\text { State agencies have prepared recommendations } \\
\text { that determine the possibility of concluding energy } \\
\text { service contracts on the basis of competitive } \\
\text { procedures. The presence of certain requirements } \\
\text { for energy producers. }\end{array}$ \\
\hline France & $\begin{array}{l}\text { The Grenelle law, adopted in 2008, plays an } \\
\text { important role in the development of energy } \\
\text { services. Energy efficiency policy is coordinated } \\
\text { by the National Energy Agency (ADEME). There } \\
\text { is a working group on public-private partnership in } \\
\text { the field of energy services. }\end{array}$ \\
\hline Great Britain & $\begin{array}{l}\text { One of the most developed energy service markets } \\
\text { and one of the first countries to widely implement } \\
\text { the energy management contract - Contract Energy } \\
\text { Management (CEM). Also one of the first to } \\
\text { introduce the BEEP (Building Energy Efficiency } \\
\text { Program). }\end{array}$ \\
\hline Austria & $\begin{array}{l}\text { A federal real estate management company that } \\
\text { deals with energy service contracts. }\end{array}$ \\
\hline Sweden & $\begin{array}{l}\text { The Forum for Energy Services and the Swedish } \\
\text { Energy Agency dealing with energy services }\end{array}$ \\
\hline Italy & $\begin{array}{l}\text { There are two associations of energy service } \\
\text { companies AGES and ASSOESCO, coordinating } \\
\text { programs in the field of energy saving and } \\
\text { promoting energy services. }\end{array}$ \\
\hline
\end{tabular}

\section{CONCLUSION}

The still high energy intensity of the Russian economy has serious consequences associated with the inefficient use of almost all types of energy resources, which negatively affects all spheres of human activity in our country. The potential for energy savings is still very significant. The experience of other countries shows that, first of all, it is necessary to improve the energy efficiency of buildings and structures of urban infrastructure and housing. Today, the scale of activities of Russian energy service companies is incomparably small compared to the amount of work required.

The world practice of energy saving projects shows that real success in this area can be achieved only as a result of coordinated actions of state structures of all levels, private energy service companies and consumers of energy resources. [16]. Only in this way can preconditions be created for the massive implementation of energy conservation projects in all sectors of the Russian economy.

\section{References}

[1] S.V. Zubkov, "Energy service contract as a mechanism of improving energy efficiency" ["Energoservisnyy kontrakt, kak mekhanizm povysheniya energeticheskoy effektivnosti”] Economics and management of innovative technologies [Ekonomika i menedzhment innovatsionnykh tekhnologiy], 2015, vol. 12(51), pp. 90-92. (In Russ.).

[2] O.A. Polyanskay and V.V. Bespalova, "Energy service contract as a way to save working capital in the public sector" ["Energoservisnyy kontrakt kak sposob ekonomii oborotnykh sredstv v byudzhetnoy sfere"]. Tax and finance [Nalogi i finansy], 2016, vol. 3(31), pp. 45-48. (In Russ.).

[3] A.I. Mikhaylova and S.N. Kladkina, "Energy service contract: application in Russia" ["Energoservisnyy kontrakt: primeneniye v Rossii"] Infrastructure sectors of the economy: problems and prospects [Infrastrukturnyye otrasli ekonomiki: problemy i perspektivy], 2016, vol. 13, pp. 100-108. (In Russ.).

[4] A.S. Gorshkov, "What hinders the implementation of energy saving in Russia" ["Chto tormozit vnedreniye energosberezheniya v Rossii"]. Energy saving [Energosberezheniye], 2015, vol. 6, pp. 46-49. (In Russ.).

[5] L.YU. Spitsina, "Energy service contract for state and municipal needs as an institute for energy saving in Russia" ["Energoservisnyy kontrakt dlya gosudarstvennykh i munitsipal'nykh nuzhd kak institut energosberezheniya v Rossii"]. Modern problems of science and education [Sovremennyye problemy nauki i obrazovaniya], 2015, vol. 1, pp. 640-646. (In Russ.).

[6] A.V. Tulikov, Energoservis - chto na povestke dnya [Energoservice what's on the agenda], Energy saving [Energosberezheniye], 2015, vol. 7, pp. 8-15. (In Russ.).

[7] F. Polzin, P. von Flotow and C. Nolden, "Modes of governance for municipal energy efficiency services - The case of LED street lighting in Germany", Journal of Cleaner Production, 2016, vol. 139, pp. 133145.

[8] C. Bratt, S. Hallstedt, K.-H. Robèrt, G. Broman and J. Oldmark, "Assessment of criteria development for public procurement from a strategic sustainability perspective", Journal of Cleaner Production, 2013, vol. 52, pp. 309-316.

[9] F. Polzin, P. von Flotow and C. Nolden, "What encourages local authorities to engage with energy performance contracting for retrofitting? Evidence from German municipalities", Energy Policy, 2016, vol. 94, pp. 317-330.

[10] A.Ye. Kiryudcheva and D.V. Nemova, "Energy service contract in Russia and the European Union" ["Energoservisnyye kontrakt v Rossii i Yevropeyskom Soyuze"]. Construction of unique buildings and structures [Stroitel'stvo unikal'nykh zdaniy i sooruzheniy], 2017, vol. 10(61), pp. 7-21. (In Russ.).

[11] E. Cagno and A. Trianni, "Evaluating the barriers to specific industria energy efficiency measures: an exploratory study in small and mediumsized enterprises", Journal of Cleaner Production, 2014, vol. 82, pp. 70-83.

[12] C. Nolden, S. Sorrell and F. Polzin, "Catalysing the Energy service market: The role of intermediaries". Energy Policy, 2016, vol. 98, pp. 20-43.

[13] O. Deng, X. Jiang and O. Cui, "Zang Strategic design of cost savings guarantee in energy perfomance contracting under uncertainty", Applied Energy, 2015, vol. 139, pp. 68-80.

[14] P. Principi, F. Roberto, Al. Carbonari and M. Lemma, "Evaluation of energy conservation opportunities through Energy Performance Contracting: A case study in Italy". Energy and Buildings, 2016, vol. 128 , pp. 886-899.

[15] O.A. Polyanskaya, V.N. Tatarenko, V.V. Bespalova, O.E. Shaitarova and I.N. Igotti, "Energy service companies and modeling of their activities in the context of growing energy intensity of the digital economy and risks". Journal of Advanced Research in Dynamical and Control Systems. 2019, vol. 11(10). pp. 159-164. (In Russ.). DOI: https://doi.org/10.5373/JARDCS/V11SP10/20192787

[16] N. Hufen and H. de Bruijn, "Getting the incentives rigt. Energy performance contracts as a tool for property management by local government", Journal of Cleaner Production, 2016, vol. 112(4), pp. 2717-2729. 